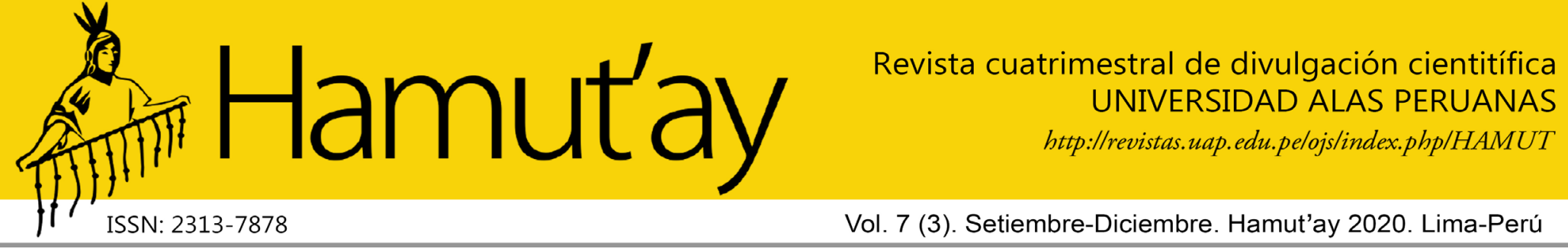

\title{
Editorial
}

\section{Impactos generados en época de pandemia}

\section{Impacts generated in times of pandemic}

\author{
Cleofé Genoveva Alvites-Huamaní \\ https://orcid.org/0000-0001-6328-6470 \\ Editor en jefe de la revista científica Hamut'ay \\ Universidad Alas Peruanas, Perú
}

\section{Cita Recomendada}

Alvites-Huamaní, C. (2020). Transformaciones en época de pandemia. Hamut’ay, 7(2), http://dx.doi.org/10.21503/hamu.v7i3.2188

\section{Introducción}

Cuando a nivel mundial todos estaban con la expectativa de iniciar un nuevo año con buenos augurios de éxitos y prosperidad, debido a los nuevos descubrimientos que la ciencia había hecho en diversos ámbitos y las tecnologías rompieron fronteras y tiempo de todo tipo a nivel globalizado y la economía se estabilizaba y mejoraba a nivel mundial, y sin presagiar lo que nos deparaba el 2020, el 31 de diciembre del 2019 se notifica un conglomerado de casos de neumonía en la ciudad de Wuhan, China, (Leiva-Cepas, Romero-Rodríguez \& Barroso, 2020) y lo que en un comienzo era algo imperceptible, el 12 de marzo del 2020 se confirma la aparición de este nuevo tipo de virus, llamado "COVID-19", desde ese momento todo cambio, ya que comenzó la propagación a nivel mundial con una rapidez exponencial (OMS, 2020), para lo cual ningún país estuvo preparado ni las potencias, más aun cuando la propagación llego al punto de ser considerada una pandemia, se empezaron a establecer medidas más restrictivas y entre las más conocidas es el inicio de la cuarentena, luego el confinamiento y el aislamiento social, lo que genero muchos cambios en la vida social y cultural. Al respecto Lima et al., (2020) refiere que estos aspectos pueden afectar el bienestar físico y psicológico y lo primero en observarse seria la pérdida de hábitos y rutinas, así como el estrés psicosocial conllevando a un

\section{Introduction}

When at the global level everyone was expecting to start a new year with good omens of success and prosperity, due to the new discoveries that science had made in various fields and technologies broke borders and time of all kinds at a globalized level and the economy stabilized and improved worldwide, and without foreshadowing what 2020 was in store for us, on December 31, 2019 a cluster of pneumonia cases was reported in the city of Wuhan, China, (Leiva-Cepas, Romero-Rodríguez \& Barroso, 2020) and what at first was something imperceptible, on March 12, 2020 the appearance of this new type of virus, called "COVID-19", was confirmed, from that moment on all changes, since the spread to world level with exponential rapidity (OMS, 2020), for which no country was prepared nor were the powers, even more so when the spread reached the point of being considered a pandemic, more restrictive measures were established and among the best known is the beginning of quarantine, then confinement and social isolation, which generated many changes in social and cultural life. In this regard, Lima et al., (2020) refer that these aspects can affect physical and psychological well-being and the first thing to be observed would be the loss of habits and routines, as well as psychosocial stress leading to a psychological impact such as fear of virus infection and diseases, the 
impacto psicológico como es el miedo a la infección por virus y enfermedades, la manifestación de sentimientos de frustración y aburrimiento, no poder cubrir las necesidades básicas y no disponer de información y pautas de actuación claras o la presencia de problemas de salud mental previos o problemas económicos; así como también el estigma y rechazo social en el caso de personas infectadas o expuestas a la enfermedad son desencadenante de una peor adaptación (Xiao et al., 2020). Pero los cambios no solo se han dado a nivel emocional, sino en todos los ámbitos desde la educación hasta la economía.

\section{Impacto negativo de la COVID-19}

Ya es casi un año que se viene conviviendo con la COVID-19 y se observa claramente que ya hay muchos cambios en la vida "normal" que se tenía antes de la pandemia. El principal o más evidente es la dependencia de la tecnología, al permanecer más tiempo en casa, esta se vuelve cada vez más parte de la rutina de muchos. Sobre todo, si se considera que las actividades educativas como laborales ahora se deben realizar de manera virtual, así como las transacciones bancarias y de otra índole se realizan en línea.

Desde otra mirada esta pandemia ha sido contraproducente porque ha generado también una paralización de la actividad económica (Lauda-Rodríguez et al., 2020), ya que no toda la fuerza empresarial se ha podido apropiar de las tecnologías y ha tenido consecuencias impredecibles en muchos países como un crecimiento negativo del PBI, el desempleo está aumentando a un ritmo vertiginoso; el comercio mundial se ha reducido; el precio del petróleo está en mínimos históricos y las bolsas se han hundido. Todo ello ha obligado a intervenciones, tanto de los bancos centrales, quienes están aplicando políticas fiscales expansivas tanto en materia sanitaria, como en apoyo del sector empresarial, fomentando el empleo y el consumo (Boscá et al., 2020). Es una disrupción que se extiende de la salud, a la economía y al sistema financiero (Ciappina, 2020). Muchos de los países en vías de desarrollo, así como otros en diversos continentes, tienen una manifestation of feelings of frustration and boredom, not being able to cover basic needs and not having information and clear guidelines for action or the presence of previous mental health problems or financial problems; as well as stigma and social rejection in the case of people infected or exposed to the disease are the trigger for a worse adaptation (Xiao et al., 2020). But the changes have not only occurred on an emotional level, but in all areas from education to the economy.

\section{Negative impact of COVID-19}

It is almost a year that we have been living with Covid-19 and it is clearly observed that there are already many changes in the "normal" life that was had before the pandemic. The main or most obvious is the dependence on technology, by staying longer at home, this becomes more and more part of the routine of many. Above all, if it is considered that educational and work activities must now be carried out virtually, as well as banking and other transactions are carried out online.

From another perspective, this pandemic has been counterproductive because it has also generated a paralysis of economic activity (Lauda-Rodríguez et al., 2020), since not all the business force has been able to appropriate the technologies and it has had unpredictable consequences in many countries as a negative GDP growth, unemployment is rising at a dizzying rate; world trade is down; the price of oil is at record lows and the stock markets have collapsed. All this has forced interventions, both by central banks, who are applying expansive fiscal policies both in health matters, as well as in support of the business sector, promoting employment and consumption (Boscá et al., 2020). It is a disruption that extends from health, to the economy and to the financial system (Ciappina, 2020).

Many of the developing countries, as well as others on various continents, have great concern because health systems are precarious and population confinement is impractical. It is therefore even reasonable to think that the effects of 
gran preocupación debido a que los sistemas sanitarios son precarios y el confinamiento de la población es impracticable. Es por lo tanto hasta razonable pensar que es muy probable que los efectos de la pandemia se diluyan allí donde la malaria, el SIDA, las enfermedades intestinales o la simple desnutrición matan anualmente a millones de personas, y alrededor del $50 \%$ de la población son menores de 15 años y viven en situación de pobreza. Las víctimas de COVID-19 expirarán entre la indiferencia y la miseria habituales, y probablemente ni siquiera pasen a formar parte de las estadísticas reales (Riggirozzo, 2020). Pero no solo hay una afectación sobre estos aspectos sino esta pandemia puede reforzar la tendencia al autoritarismo político si no se hace una enseñanza precisa a la población, por lo que es necesario diferenciar la aplicación de medidas de control y restricción de libertades en situaciones excepcionales de la normalidad ciudadana, evitando caer en la habitual tendencia histórica a que lo excepcional termine por convertirse en algo cotidiano, (Bacolla et al., 2020).

Sumado a lo mencionado, la evidencia de los efectos psicológicos es también preocupante, en un estudio realizado en China aplicado en una encuesta a 1.210 personas de las cuales valoraba el impacto psicológico de la situación como moderado-grave en un 53\%, mientras que el 16\% refería síntomas depresivos entre moderados o graves, el 28\% síntomas de ansiedad a nivel moderado y el $8 \%$ niveles de estrés grave. Para la mayoría la principal preocupación (75\%) fue que sus familiares se contagiaran de coronavirus (Pan et al., 2020). En otro estudio con residentes de Wuhan y ciudades cercanas realizado un mes después de que se declarara el brote de COVID-19, hallaron una prevalencia de síntomas de estrés postraumático del 7\% (Liu et al., 2020). Posteriormente, el mismo grupo y con una muestra más amplia de 2.091 personas, perteneciente a la China continental, hallaron una prevalencia de síntomas de estrés postraumático agudo un mes después del brote de COVID-19 del 4,6\% (Sun et al., 2020). Un trabajo en España, otro país muy afectado con este virus, un 30,4\% evidenció un impacto psicológico severo, un $6,2 \%$ informa- the pandemic are very likely to be diluted where malaria, AIDS, intestinal diseases or simple malnutrition kill millions of people annually, and around $50 \%$ of the population are under 15 years of age and live in poverty. COVID-19 victims will expire amidst habitual indifference and misery, and will likely not even become part of the actual statistics (Riggirozzo, 2020). But not only is there an impact on these aspects, but this pandemic can reinforce the tendency to political authoritarianism if the population is not taught precisely, so it is necessary to differentiate the application of control measures and restriction of freedoms in exceptional situations from citizen normality, avoiding falling into the usual historical tendency for the exceptional to end up becoming something every day (Bacolla et al., 2020).

In addition to the aforementioned, the evidence of the psychological effects is also worrying, in a study carried out in China applied to a survey of 1,210 people, of whom $53 \%$ assessed the psychological impact of the situation as moderate-severe, while the $16 \%$ reported moderate or severe depressive symptoms, $28 \%$ moderate anxiety symptoms and $8 \%$ severe stress levels. For the majority, the main concern (75\%) was that their relatives would be infected with coronavirus (Pan et al., 2020). In another study with residents of Wuhan and nearby cities conducted a month after the COVID-19 outbreak was declared, they found a prevalence of PTSD symptoms of 7\% (Liu et al., 2020). Subsequently, the same group and with a larger sample of 2,091 people, belonging to mainland China, found a prevalence of acute post-traumatic stress symptoms one month after the COVID-19 outbreak of 4.6\% (Sun et al., 2020). A study in Spain, another country very affected by this virus, $30.4 \%$ showed a severe psychological impact, $6.2 \%$ reported a moderate psychological impact; $14.4 \%$ scored in the range of mild psychological impact and $49 \%$ reported minimal psychological impact. While for anxiety $69.3 \%$ were considered to have normal levels of anxiety, $5.3 \%$ showed mild anxiety, $11.3 \%$ showed moderate anxiety, $4.8 \%$ showed severe anxiety and $9.2 \%$ showed extreme anxiety severe. For depression, 59.1\% showed normal levels, 
ron un impacto psicológico moderado; un 14,4\% puntuaron en el rango de impacto psicológico leve y $49 \%$ informaron un impacto psicológico mínimo. Mientras que para la ansiedad se consideró que un $69,3 \%$ tenían niveles normales de ansiedad, un 5,3\% mostraron ansiedad leve, un $11,3 \%$ mostraron ansiedad moderada, un $4.8 \%$ mostraron ansiedad severa y el 9.2\% mostraron ansiedad extremadamente severa. Para la depresión, el 59,1\% mostraron niveles normales, $11,4 \%$ tienen depresión leve, $14,8 \%$ tienen depresión moderada, $6,3 \%$ presentaron depresión grave y el $8,5 \%$ mostraron depresión extremadamente grave (Rodríguez et al., 2020).

\section{Impacto positivo de la COVID-19}

Aunque no todos los resultados son muy halagüeños, no podemos dejar de mencionar, que el 2020 también trajo aspectos positivos que resaltar como la tecnología de la información y comunicación (TIC) dejo de ser un medio accesorio a ser una herramientas indispensable en todo momento, lugar, espacio y nivel, a pesar de que formaba parte de nuestra vida, podíamos estar sin ella, pero en estas circunstancias ha servido para unir familias lo que no permitió perder la vinculación social, en la educación al ser el medio para las clases remotas, en la banca al poder realizar transacciones en línea y sobre todo rescatar la relevancia en la salud, ya que abrió fronteras para la telemedicina, realizar tele consultas, acompañamiento virtual psicológico, monitoreos remotos y una diversidad de apoyo al público usuario en salud respetando las normas de confinamiento y la no exposición ante el virus (Reyes, 2020). Otro aspecto resaltante es la educación, impensable, pero paso a ser una prioridad de los gobiernos de turnos, para contrarrestar el cierre de escuelas por la COVID-19 muchos países utilizaron una diversidad de recursos para apoyar el aprendizaje de los estudiantes desde el envió de paquetes educativos hasta la utilización de la radio, la televisión y una diversidad de herramientas tecnológicas siendo las plataformas en línea las que fueron más utilizadas, (OECD, 2020) obligando de esta manera a que los docentes se
$11.4 \%$ had mild depression, $14.8 \%$ had moderate depression, $6.3 \%$ had severe depression, and 8.5\% showed extremely severe depression (Rodríguez et al., 2020).

\section{Positive impact of COVID-19}

Although not all the results are very promising, we cannot fail to mention that 2020 also brought positive aspects to highlight as information and communication technology (ICT) stopped being an accessory medium to being an indispensable tool at all times, place, space and level, although it was part of our life, we could be without it, but in these circumstances it has served to unite families which did not allow us to lose social ties, in education as it is the means for remote classes, in banking by being able to carry out online transactions and above all to rescue the relevance in health, since it opened borders for telemedicine, tele-consultations, virtual psychological support, remote monitoring and a diversity of support to the public user in health respecting the norms of confinement and non-exposure to the virus (Reyes, 2020).

Another outstanding aspect is education, unthinkable, but it became a priority of shift governments, to counter the closure of schools due to COVID-19, many countries used a variety of resources to support student learning since the sending of educational packages to the use of radio, television and a variety of technological tools, online platforms being the most used, (OECD, 2020) thus forcing teachers to self-train in the use of technologies, that for many years it was a weakness.

In the business field, many of the medium and small companies have understood that for their reactivation it is not only to look for infrastructure and physical presence but that they become obsolete but they digitize their services or if they do not use social networks, digital marketing or other types of tools with appropriation of information and communication technology, also within this area teleworking has been a good alternative so that many do not lose their jobs (Nicolás and Rubio, 2020), since this pandemic also 
autocapacitarán en el uso de las tecnologías, que por muchos años fue una debilidad.

En el ámbito empresarial muchas de las medianas y pequeñas empresas han comprendido que para su reactivación no solo es buscar infraestructura y presencia física sino que quedan obsoletas sino digitalizan sus servicios o si no utilizan la redes sociales, el marketing digital u otro tipo de herramientas con apropiación de las tecnología de la información y comunicación, asimismo dentro de este rubro el teletrabajo ha sido una buena alternativa para que muchos no pierdan sus empleos (Nicolás y Rubio, 2020), ya que esta pandemia también nos enseñó que podemos realizar trabajo remoto con la misma calidad.

Un 2020 que no se esperaba para nada, año que sorprendió, que retó al mundo, a pesar de ello se pudo afrontar las adversidades y se logro seguir haciendo divulgación de la ciencia, año que nos enseñó a ser más solidarios que nunca, a compartir, a mirar al otro como un ser humano, de igual a igual, ya que esta pandemia nos mostró lo vulnerables que somos, sin importar etnia, credo, condición social, cultural ni lugar geográfico, todos fuimos afectados de alguna manera, pero siempre con la gracia de Dios el poder publicar un número más de la revista Hamut'ay, mil gracias a todos los autores, investigadores, pares evaluadores y cada uno de los profesionales que nos han apoyado desde el inicio de la revista en el 2014 hasta este último número del 2020, quienes siguen confiando y compartiendo su profesionalismo en aras de la divulgación científica. taught us that we can carry out remote work with the same quality.

A 2020 that was not expected at all, a year that surprised, that challenged the world, despite this, it was possible to face adversity and it was possible to continue spreading science, a year that taught us to be more supportive than ever, to share, to look at the other as a human being, as an equal, since this pandemic showed us how vulnerable we are, regardless of ethnicity, creed, social, cultural or geographical location, we were all affected in some way, but always with the Grace of God to be able to publish one more issue of Hamut'ay Journal, a thousand thanks to all the authors, researchers, peer reviewers and each of the professionals who have supported us from the beginning of the journal in 2014 to this last issue 2020, who continue to trust and share their professionalism for the sake of scientific dissemination. 


\section{Referencias Bibliográficas}

Bacolla, N., Caravaca, J., Daniel, C., Mellado, V., \& Ramaciotti, K. (2020). Política y experticia en tiempos de coronavirus. Estudios Sociales del Estado, 6(11), 1-6.

https://doi.org/10.35305/ese.v6i11.214

Boscá, J. E., Doménech, R., \& Ferri, J. (2020). El impacto macroeconómico del Coronavirus. Documentos Macroeconomía FEDEA.

Ciappina, C. (2020). Crisis del Coronavirus; la pandemia global y las disputas de sentido.¿La configuración de un orden nuevo? Una mirada desde América Latina. Question/Cuestión, 1(mayo), e280-e280. https://doi.org/10.24215/16696581e280

Lauda-Rodríguez, Z., Milz, B., Santana-Chaves, I., Campello, P. \& Jacobi, P. (2020). Editorial - La época COVID-19: investigación interdisciplinaria y una nueva ética sostenible y justa. Ambiente \& Sociedade. São Paulo, 23, 1-12.

https://doi.org/10.1590/1809-4422asoceditorialvu202013ed

Leiva-Cepas, F., Romero-Rodríguez, E. \& Barroso Sevillano. M. (2020). Las revistas científicas ante la pandemia por COVID-19. Medicina de Familia-SEMERGEN.

https://doi.org/10.1016/j.semerg.2020.06.012

Lima, C. K. T., de Medeiros Carvalho, P. M., Lima, I. D. A. S., de Oliveira Nunes, J. V. A., Saraiva, J. S., de Souza, R. I., ... \& Neto, M. L. R. (2020). The emotional impact of Coronavirus 2019-nCoV (new Coronavirus disease). Psychiatry research, 112915. https://doi.org/10.1016/j.psychres.2020.112915

Liu, J. J., Bao, Y., Huang, X., Shi, J., \& Lu, L. (2020). Mental health considerations for children quarantined because of COVID-19. The Lancet Child \& Adolescent Health, 4(5), 347-349. https://doi.org/10.1016/S2352-4642(20)30096-1

Nicolás, C. y Rubio, A. (2020). Emprendimiento en épocas de crisis: Un análisis exploratorio de los efectos de la COVID-19. Small Business International Review, 4 (2), 53-56. https://doi.org/10.26784/sbir.v4i2.279

OMS (2020). COVID-19: Cronología de la actuación de la OMS.Organización Mundial de la Salud. Recuperado de https://www.who.int/es/news-room/detail/27-04-2020who-timeline---covid-19

OECD, (2020). El impacto del COVID-19 en la educación. Información del Panorama de la Educación (Education at a Glance) 2020. Recuperado de https://www.oecd.org/ centrodemexico/medios/EAG2020_COVID\%20Brochure\%20ES.pdf

Pan, L., Wang, L., \& Huang, X. (2020). How to face the novel coronavirus infection during the 2019-2020 epidemic: the experience of Sichuan Provincial People's Hospital. https://doi.org/10.1007/s00134-020-05964-0

Reyes, W. (2020). Efectos colaterales positivos de la pandemia. Revista Uruguaya de Cardiología, 35 (2), 155-162. https://doi.org/10.29277/cardio.35.2.6

Riggirozzi, P. (2020). Coronavirus y el desafío para la gobernanza regional en América Latina. Análisis Carolina, (12), 1. https://doi.org/10.33960/AC_12.2020
Rodríguez-Rey, R., Garrido-Hernansaiz, H., \& Collado, S. (2020). Psychological impact and associated factors during the initial stage of the coronavirus (COVID-19) pandemic among the general population in Spain. Frontiers in psychology, 11, 1540.

https://doi.org/10.3389/fpsyg.2020.01540

Sun, L., Sun, Z., Wu, L., Zhu, Z., Zhang, F., Shang, Z., ... \& Liu, N. (2020). Prevalence and risk factors of acute posttraumatic stress symptoms during the COVID-19 outbreak in Wuhan, China. MedRxiv.

https://doi.org/10.1101/2020.03.06.20032425

Urzúa, A., Vera-Villarroel, P., Caqueo-Urízar, A., \& Polanco-Carrasco, R. (2020). La Psicología en la prevención y manejo del COVID-19. Aportes desde la evidencia inicial. Terapia psicológica, 38(1), 103-118.

https://doi.org/10.4067/S0718-48082020000100103

Xiao, H., Zhang, Y., Kong, D., Li, S., \& Yang, N. (2020). The effects of social support on sleep quality of medical staff treating patients with coronavirus disease 2019 (COVID-19) in January and February 2020 in China. Medical science monitor: international medical journal of experimental and clinical research, 26, e923549-1.

https://doi.org/10.12659/MSM.923921 